\title{
Mutậwầsith \\ JURNAL HUKUM ISLAM \\ TINJAUAN ISLAM TERHADAP PEMANFAATAN BARANG GADAI SAWAH DI DESA CIBERES KECAMATAN PATOKBEUSI KABUPATEN SUBANG
}

\author{
Siti Hadiyanti Dini Islamiati \\ Institut Agama Islam Nasional Laa Roiba Bogor, Indonesia \\ Email: dinihadirachman@gmail.com
}

\begin{abstract}
Abstrak
Terjadinya praktek gadai sawah di Desa Ciberes ini sudah marak sekali. Kebanyakan masyarakat khususnya petani beranggapan bahwa menggadaikan sawahnya lebih mudah dari pada harus meminjam uang ke Bank, karena tanpa harus melalui prosedur yang rumit. Setelah itu dengan kesepakatan dan rasa percaya antara kedua belah pihak maka selesai sudah transaksi tersebut. Akan tetapi jika sudah mempunyai uang sebelum jatuh tempo, maka rahin dibolehkan untuk menebus atau mengambil sawahnya kembali. Penelitian ini bertujuan untuk mengetahui pemanfaatan barang gadai sawah di Desa Ciberes, serta mengetahui tinjauan Islam terhadap pemanfaatan barang gadai sawah. Metode yang digunakan Yuridis Normatif dengan pendekatan Deskriftif Kualitatif, yaitu mengungkapkan dan menganalisis serta memberikan gambaran mengenai fakta-fakta yang telah diteliti. Pengumpulan data dilakukan dengan observasi, wawancara (interview), dan dokumentasi. Hasil penelitian menunjukan bahwa terjadinya pemanfaatan barang gadai sawah di Desa Ciberes bermula adanya ketidaksahan dalam praktek gadai disebabkan adanya kecacatan dalam shigat antara rahin dan murtahin, yakni dalam shigat yang mereka laksanakan terdapat persyaratan yang berkaitan dengan pemanfaatan marhun (sawah), secara keseluruhan berpindah ke tangan murtahin. Dan syarat tersebut merusak shigat akad. Sedangkan menurut tinjauan islam tidak sesuai karena menurut pendapat ulama tidak membolehkan adanya pemanfaatan marhun oleh murtahin, alasannya bahwa pemanfaatan marhun dapat dikategorikan dalam akad qard yang mensyaratkan tambahan tertentu, dan ini juga dapat dikategorikan macam riba. Selain itu juga pemanfaatan marhun oleh murtahin ini keluar dari ketentuan bahwa yang berhak memanfaatkan suatu barang ialah pemiliknya.

Kata Kunci: gadai, islam, pemanfaatan
\end{abstract}

\begin{abstract}
Business ethics is a study of true or false moral. People doing business aims to find as much profit as possible, even using unethical means. The conventional classic economic law controls the capital as small as possible and dredge profits as good as possible. Thus making the business people to justify everything. It's no surprise that business people do not pay attention to social responsibility and business ethics. This research aims to know the Islamic business and to know the attitudes of the traders in the market Manaqib already in accordance with Islamic business ethics. Research is done by collecting data from a variety of sources: books, magazines, journals or other writings and is supported by direct observation or observation and interviews and then then Symbolisions. The method used in this research is a descriptive method with a normative juridical approach. A normative juridical approach is an approach made based on key legal materials by examining theories, concepts, principles of law and legislation. From the results of the research found that
\end{abstract}


Tinjauan Islam Terhadap Pemanfaatan Barang Gadai Sawah Di Desa Ciberes Kecamatan Patokbeusi Kabupaten Subang

traders understand the ethical selling good by offering goods in an honest, trustworthy, polite, and do not conceal the defective goods. When it is stored by other merchants they keep it well. Traders are traders who are ethics of Islamic business, because almost all traders in the market Manaqib have applied the foundations of Islamic business ethics on the implementation of its businesses.

Keywords: business, ethics, islam, manaqib, market

\section{PENDAHULUAN}

Manusia merupakan ciptaan Tuhan Yang Maha Esa sebagai khalifah dibumi dengan dibekali akal pikiran untuk berkarya dimuka bumi. Manusia memiliki perbedaan baik secara biologis maupun rohani. Secara biologis umumnya manusia dibedakan secara fisik sedangkan secara rohani manusia dibedakan berdasarkan kepercayaannya atau agama yang dianutnya. Kehidupan manusia sendiri sangatlah komplek, begitu pula hubungan yang terjadi pada manusia dengan manusia, manusia dengan alam, manusia dengan makhluk hidup lainnya yang hidup di alam, manusia dengan Sang Pencipta. Setiap hubungan tersebut harus berjalan selaras dan seimbang. Selain itu manusia juga diciptakan dengan kesempurnaan penciptaan, dengan sebaik-baik bentuk yang memiliki. Hal ini di jelaskan dalam surat At-Tiin ayat 4 sebagai berikut: ${ }^{1}$

"Sesungguhnya kami telah menciptakan manusia dalam bentuk yang sebaik-baiknya".

Sebagai makhluk sosial tidak bisa lepas untuk berhubungan dengan orang lain dalam rangka memenuhi kebutuhan hidupnya. Kebutuhan manusia sangat beragam, terkadang secara pribadi ia tidak mampu memenuhinya, dan harus berhubungan dengan orang lain. Hubungan antara satu manusia dengan manusia lainnya dalam memenuhi kebutuhan, harus terdapat suatu aturan yang menjelaskan hak dan kewajiban antara ijab dan qobul dengan cara yang dibenarkan syara' yang menetapkan adanya akibat-akibat hukum pada objeknya.

Tujuan terciptanya hukum (syar'i) dalam menetapkan hukum-hukumnya adalah untuk mewujudkan atau menciptakan kemaslahatan hidup bagi seluruh umat manusia di muka bumi ini, menegakkan keadilan dan mendidik. ${ }^{2}$ Allah menurunkan syariat (hukum) Islam untuk mengatur kehidupan manusia, baik selaku pribadi maupun selaku anggota masyarakat di dalam mengatur/ mencakup muamalah seperti pada masalah gadai.

\footnotetext{
${ }^{1}$ http://www.quran30.net/2012/08/surat-at-tiin.html, dikutip tanggal 25 Februari 2018

2 http://statushukum.com//tujuan-hukum-islam.html, dikutip tanggal 14 April 2018
} 
Tinjauan Islam Terhadap Pemanfaatan Barang Gadai Sawah Di Desa Ciberes Kecamatan Patokbeusi Kabupaten Subang

Pengertian Gadai terungkap dalam Pasal 1150 Kitab Undang- Undang Hukum Perdata ${ }^{33}$ adalah suatu hak yang diperoleh seseorang yang mempunyai piutang atas sesuatu barang yang bergerak, yaitu barang yang bergerak tersebut diserahkan kepada orang yang berpiutang oleh orang yang mempunyai utang atau orang lain atas nama orang yang mempunyai utang. Karena itu, makna gadai (rahn) dalam bahasa hukum yang artinya:

"Menjadi sesuatu barang yang mempunyai nilai harta dalam pandangan syara' sebagai jaminan utang, yang memungkinkan untuk mengambil seluruh atau sebagian utang dari barang tersebut".

Sedangkan definisi akad ar-Rahnu menurut istilah syara' yang dikutip oleh Wahbah Az-Zuhaili4 ${ }^{4}$ adalah, menahan sesuatu disebabkan adanya hak yang memungkinkan hak itu bisa dipenuhi dari sesuatu tersebut. Maksudnya, menjadikan al-'Ain (barang, harta yang barangnya berbentuk konkrit, kebalikan dari ad-Dain atau utang) yang memiliki nilai menurut pandangan syara', sebagai watsiiqah (pengukuhan, jaminan) utang, sekiranya barang itu memungkinkan untuk digunakan membayar seluruh atau sebagian utang yang ada. Atau arRahnu adalah akad watsiiqah (penjaminan) harta, maksudnya sebuah akad yang berdasarkan atas pengambilan jaminan yang berbentuk harta yang konkrit bukan jaminan dalam berbentuk tanggungan seseorang.

Oleh karena itu, ar-Rahnu berbeda dengan akad al-Kafaalah, karena atTawatstsuq (penjaminan) di dalam akad al-Kafaalah adalah dengan tanggungan pihak kafiil (pihak yang menjamin) bukan dengan harta konkrit yang dipegang oleh pihak ad-Daa'in (yang berpiutang). Kata watsiiqah artinya adalah sesuatu yang dijadikan penguat atau jaminan. Karena utang yang ada di dalam akad ar-Rahnu (al-Marhuun). Adapun sesuatu yang digadaikan dan dijadikan watsiiqah haruslah sesuatu yang memiliki nilai, maka itu untuk mengecualikan al-'Ain (barang) yang najis dan barang yang terkena najis yang tidak mungkin untuk dihilangkan, karena kedua bentuk al-'Ain ini (yang najis dan terkena najis yang tidak mungkin dihilangkan) tidak bisa digunakan sebagai watsiiqah (jaminan) utang.

Praktek seperti ini telah ada sejak zaman Rasulullah SAW, dan Rasul sendiri pernah mengatakannya. Gadai mempunyai nilai sosial yang sangat tinggi dan dilakukan secara sukarela atas dasar tolong-menolong. Gadai atau Rahn dalam

${ }^{3}$ Kitab Undang-Undang Hukum Perdata", Tangerang Selatan: SL Media, 2010 hlm. 286.

${ }^{4}$ Wahbah Az-Zuhaili, "Fiqih Islam Wa Adillatuhu Jilid 6", (Jakarta: Gema Insani, 2011), hlm. 107. 
Tinjauan Islam Terhadap Pemanfaatan Barang Gadai Sawah Di Desa Ciberes Kecamatan Patokbeusi Kabupaten Subang

syariat Islam dikategorikan sebagai perbuatan jaiz atau boleh menurut ketentuan Al-Qur'an, As-Sunnah, dan Ijma'. Landasan normatif masalah itu sendiri adalah ayat-ayat Al-Qur'an dalam Surat Al-Baqarah ayat 283 yang berbunyi sebagai berikut: 5

"Jika kamu dalam perjalanan (dan bermuamalah tidak secara tunai) sedang kamu tidak memperoleh seorang penulis, maka hendaklah ada barang tanggungan yang dipegang (oleh yang berpiutang). Akan tetapi, jika sebagian kamu mempercayai itu menunaikan amanatnya (utangnya) dan hendaklah ia bertakwa kepada Allah Tuhannya; dan janganlah kamu (para saksi) menyembunyiakan persaksian. Dan barangsiapa yang menyembunyikannya, maka sesungguhnya ia adalah orang berdosa hatinya; dan Allah Maha Mengetahui apa yang kamu kerjakan.".

Perkembangan mengenai Pegadaian tidak hanya tumbuh dan berkembang pesat di pegadaian-pegadaian yang berada di bawah naungan kelembagaan, baik lembaga Konfensional maupun lembaga Syari'ah. Tetapi pegadaian perorangan juga tidak kalah berkembang dari pegadaian- pegadaian lain. Hal ini terbukti dengan maraknya transaksi gadai sawah yang dilakukan masyarakat di Desa Ciberes Kecamatan Patokbeusi Kabupaten Subang. Masyarakat Desa Ciberes dalam bertransaksi gadai ialah dengan cara orang yang menggadaikan (rahin) menyerahkan sawahnya sebagai jaminan (borg) kepada orang yang menerima gadai (murtahin).

Kebanyakan masyarakat Desa Ciberes Kecamatan Patokbeusi Kabupaten Subang khususnya para petani, beranggapan bahwa menggadaikan sawahnya lebih mudah dari pada harus meminjamkan uang di Bank, Pegadaian, maupun Koperasi, karena tanpa harus melalui prosedur-prosedur yang rumit. Hanya dengan kesepakatan dan dengan rasa kepercayaan antara kedua belah pihak maka selesai sudah transaksi tersebut. Sebagai contoh, misalnya Bapak A yang menggadaikan sawahnya seluas 1 bau kepada Bapak B sebesar dua ratus ribu juta rupiah (Rp. 200.000.000).

Dalam hal ini sawah yang dijadikan jaminan tersebut tidak dapat diambil selama kurang dari dua (2) kali panen padi selama satu (1) tahun. Setelah itu biasanya lahan sawah (marhun) yang dijaminkan tersebut digarap oleh si penerima gadai (murtahin), akan tetapi jika sudah mempunyai uang tersebut sebelum jatuh tempo yang sudah ditentukan, maka pemberian gadai (rahin) dibolehkan untuk

${ }^{5}$ http://www.quran30.net/2012/08/surat-al-baqarah.html, dikutip tanggal 25 Februari 2018 
Tinjauan Islam Terhadap Pemanfaatan Barang Gadai Sawah Di Desa Ciberes Kecamatan Patokbeusi Kabupaten Subang

menebus atau mengambi sawahnya kembali. ${ }^{6}$ Hal ini dikarenakan untuk mencegah timbulnya kerugian atas sawah yang telah dikelola oleh penerima gadai (murtahin) selama masa pemegangan sawah gadaian (borg) tersebut.

Berangkat dari permasalahan diatas, maka merasa perlu mengadakan penelitian sehingga khususnya masyarakat Desa Ciberes Kecamatan Patokbeusi Kabupaten Subang dan umumnya pembaca dapat mengetahui transaksi gadai sawah yang bagaimana yang diperbolehkan dan yang tidak diperbolehkan oleh agama karena mayoritas penduduknya beragama Islam.

\section{METODOLOGI PENELITIAN}

Metode yang digunakan dalam tulisan ini adalah metode yuridis normatif yaitu suatu penelitian yang secara deduktif dimulai analisa terhadap pasal-pasal dalam peraturan perundang-undangan yang mengatur terhadap permasalahan diatas. Penelitian hukum secara yuridis maksudnya penelitian yang mengacu pada studi kepustakaan yang ada ataupun terhadap data sekunder yang digunakan. Sedangkan bersifat normatif tentang perhubungan antara satu peraturan dengan peraturan lain dan penerapan dalam prakteknya. $^{7}$

Dalam hal ini adalah mengenai persoalan yang berkaitan dengan Tinjauan Hukum Islam Terhadap Praktek Gadai Sawah di Desa Ciberes Kecamatan Patokbeusi Kabupaten Subang. Disamping itu juga, penulis juga menggunakan buku-buku dan literatur-literatur penunjang yang mengemukakan berbagai teori hukum dan dalil-dalil yang berhubungan dengan masalah yang dikaji. Jenis pendekatan yang digunakan adalah deskriptif kualitatif.

\section{Jenis Data}

Sebagai jawaban atas pertanyaan penelitian yang diajukan terhadap masalah yang dirumuskan dan pada tujuan yang telah ditetapkan, maka jenis data yang dikumpulkan dalam penulisan ini adalah data kualitatif, data yang digambarkan dengan kata-kata atau kalimat. Jenis data tersebut kemudian diklasifikasikan sesuai butir- butir pertanyaan yang diajukan, serta menghindarkan dari jenis data yang tidak relevan dengan pertanyaan tersebut, walaupun dimungkinkan penambahan sebagai pelengkap.

\section{Sumber Data}

${ }^{6}$ Endang Sutisna, Orang Tua peneliti, wawancara, Subang, 21 Februari 2018
7 Zainuddin Ali, "Hukum Gadai Syariah", Jakarta: Sinar Grafika, 2008, hlm. 42. 
Tinjauan Islam Terhadap Pemanfaatan Barang Gadai Sawah Di Desa Ciberes Kecamatan Patokbeusi Kabupaten Subang

Sumber data yang dihimpun penulis dalam penyusunan tulisan ini terdiri dari dua (2) macam sumber, yaitu: Pertama, Sumber Data Primer, yaitu sumber data pokok yang dijadikan rujukan utama. Sumber utama yang dijadikan bahan penelitian dalam penulisan penelitian ini dan karena penelitian ini penelitian lapangan data yang diperoleh dari sumber-sumber ahli yang memberi informasi langsung dalam penelitian dari data tersebut. Kedua, Sumber Data Sekunder, yaitu sumber data pendukung, artinya literatur yang mendukung atau melengkapi terhadap sumber data primer. Dalam penelitian ini, yang dijadikan sumber data sekunder adalah buku-buku referensi yang akan melengkapi hasil observasi dan wawancara yang telah ada.

\section{Teknik Pengumpulan Data}

Dalam teknik pengumpulan data ini penulis menggunakan beberapa metode, yaitu: Observas, dengan teknik ini, penulis mengamati dan mencatat halhal yang perlu diteliti, yaitu Pemanfaatan Barang Gadai Sawah yang dilakukan di Desa Ciberes Kecamatan Patokbeusi Kabupaten Subang. Penulis mengamati berbagai peristiwa dengan cara terlibat langsung dilapangan lokasi penelitian. Sehingga dengan teknik ini, akan membantu penulis untuk mengetahui seperti apa Pemanfaatan Barang Gadai Sawah yang dilakukan di Desa Ciberes Kecamatan Patokbeusi Kabupaten Subang.

Wawancara (Interview), adalah suatu cara yang dipergunakan seseorang untuk tujuan tertentu guna mendapatkan keterangan secara lisan dan jelas. ${ }^{8}$ Dengan teknik ini data dikumpulkan dengan cara wawancara langsung kepada para penggadai sawah dan menyampaikan pertanyaan-pertanyaan dengan apa yang penulis teliti. Dokumentasi, dokumentasi yang digunakan adalah dokumentasi untuk mencari data-data mengenai hal-hal atau variabel yang berupa catatan, transkip buku, notulen, rapat, legger, agenda dan sebagainya.

\section{Analisis Data}

Menurut Aji Damanuri, ${ }^{9}$ analisis data terdiri dari analisa kualitatif, maksudnya data yang tidak berbentuk angka-angka melainkan kata-kata. Analisis data menurut Patton yang dikutif oleh Lexy J Monoeng adalah proses mengatur urutan data, mengorganisasikan ke dalam suatu pola, kategori manapun satuan uraian dasar, mengorganisasikannya ke dalam uraian dasar. Analisis pekerjaannya dalam mengatur, mengurutkan, mengkelompokkan, dan memberi kode. ${ }^{10}$

\footnotetext{
${ }^{8}$ Adi Riyanto, "Metodologi Penelitian Sosial dan Hukum", (Jakarta: Granit, 2004), hlm. 20.

${ }^{9}$ Aji Damanuri, Metodologi Penelitian Muamalah, (Yogyakarta: Stain Po Press, 2010), hlm. 84.

${ }^{10}$ Lexy J. Monoeng, "Metode Penelitian Kualitatif", (Bandung, PT. Remaja Rosdakarya, 2000),
} hlm. 103. 
Tinjauan Islam Terhadap Pemanfaatan Barang Gadai Sawah Di Desa Ciberes Kecamatan Patokbeusi Kabupaten Subang

Selanjutnya disimpulkan dalam bentuk penelitian dengan kalimat yang mudah dimengerti. Langkah-langkah kongkrit untuk menetapkan teknik analisis data ini adalah dengan mengungkapkan tentang Tinjauan Islam terhadap Pemanfaatan Barang Gadai Sawah di Desa Ciberes Kecamatan Patokbeusi Kabupaten Subang.

\section{PEMBAHASAN HASIL PENELITIAN}

\section{Pemanfaatan Barang Gadai Sawah di Desa Ciberes Kecamatan Patokbeusi Kabupaten Subang}

Gadai dalam pandangan masyarakat Desa Ciberes digambarkan dengan suatu kegiatan utang-piutang dengan menjaminkan harta benda atau barang berharga, yang di jadikan jaminannya yaitu lahan persawahan. Barang jaminan tersebut biasanya diserahkan kepada murtahin (penerima gadai) oleh rahin (pemberi gadai). Setelah itu barang jaminan si rahin oleh si murtahin biasanya dikuasai bahkan dimanfaatkan pula oleh si murtahin, sampai si rahin dapat mengembalikan utang yang diambilnya. Alasan utama yang melatarbelakangi dilaksanakannya akad gadai sawah di Desa Ciberes ialah karena masalah si rahin tersebut mengalami ekonomi yang mendesak, sehingga ia menggadaikan sawahnya. Menurut Pak Ujang biasanya si rahin menggadaikan sawahnya dikarenakan kekurangan modal, seperti biaya berobat ke rumah sakit, untuk hajatan, bahkan untuk modal naik haji ketanah suci, dan lain-lain. ${ }^{1163}$ Sedangkan menurut Ibu Iroh mengatakan bahwa proses menggadaikan sawah dengan Lembaga Keuangan itu lebih sulit dibandingkan dengan sesama masyarakat, kalau dengan sesama masyarakat lebih mudah cepat dan tak ada proses atau tahapan-tahapan yang rumit dibandingkan menggadaikan

uang ke Lembaga Keuangan yang membingungkan. ${ }^{1264}$ Berkaitan dengan alasan ini salah satunya disampaikan oleh Ibu Iroh, bahwa saat beliau akan memulai menggarap sawah, beliau kemudian menggadaikan sebagian lahan sawah yang dimilikinya untuk dijadikan utang yang diambilnya yang kemudian akan dijadikan sebagai modal menggarap sawahnya tersebut, seperti memberi upah pekerja garapan sawah, beli pupuk, dan lain-lain. Beliau berpendapat menggadaikan lahan sawah yang dimilikinya itu merupakan cara yang efesien untuk mendapatkan modal. Hal itu tentu berbeda jika kemudian ia mengambil pendanaan dari lembaga keuangan (Bank), tentu akan melalui prosedur yang rumit dan memerlukan waktu yang lama. Selain itu, pendanaan melalui lembaga keuangan

\footnotetext{
11 Ujang Rohman, Paman Penulis, wawancara, Subang, 5 Juni 2018

${ }^{12}$ Iroh, Orang Tua Penulis, wawancara, Subang, 22 Juni 2018
} 
Tinjauan Islam Terhadap Pemanfaatan Barang Gadai Sawah Di Desa Ciberes Kecamatan Patokbeusi Kabupaten Subang

akan membawa masalah lainnya, yakni beliau harus melakukan pengangsuran disaat hasil panen padi itu belum tentu untung dan ruginya.

Pak Obing dan Pak Dedi menjelaskan bahwa sisi alasan si murtahin melakukan praktek gadai, terdapat jenis praktek gadai sawah di Desa Ciberes. ${ }^{1365}$ Pertama, gadai sawah karena alasan sosial, yakni murtahin melaksanakan akad gadai karena ia bermaksud untuk membantu rahin, dalam hal ini murtahin sudah melihat letak dan luas sawah yang dijadikan jaminan. Kedua, gadai sawah karena alasan komersial, yakni murtahin mengambil gadai tersebut karena ia bermaksud untuk mengambil keuntungan dan manfaat atas sawah yang dijadikan jaminan tersebut, dalam hal ini murtahin akan melihat letak dan luas sawah yang dijadikan jaminan tersebut, serta menjadikannya sebagai pertimbangan berapa besar ia akan memberikan pinjaman pada rahin. Maksudnya ialah semakin besar pinjaman yang diambil, maka penguasaan murtahin atas sawah gadai tersebut semakin lama juga. Ini seperti dijelaskan oleh Ibu Nuryati, menurutnya daripada uang yang dimilikinya didiamkan saja, ia kemudian mengambil gadai yang ditawarkan kepadanya itu itung-itung menabung. ${ }^{14}$

Selanjutnya berkenaan dengan pelaksanaan praktek gadai sawah tersebut dijelaskan oleh Ibu Iroh bahwa pelaksanaan praktek gadai diawali dengan proses dimana pihak pemberi gadai (rahin) terlebih dahulu memberi tahu besarnya uang yang akan dipinjam dan menawarkan barang yang akan dijadikan barang jaminan (berupa sawah) kepada si penerima gadai (murtahin).

Kemudian si penerima gadai (murtahin) menaksir luas tanah sawah dengan uang. Ibu Iroh menjelaskan bahwa seperti beliau pernah juga melaksanakan akad gadai saat beliau akan memulai menggarap sawah dengan menggadaikan sebagian sawahnya seluas 200 bata $^{67}$ dan beliau dapat mengambil uang sebesar Rp. 20 Juta dari Ibu Nuryati yang dalam hal ini bertindak sebagai penerima gadai (murtahin). Sebelumnya terjadi tawar-menawar antara kedua belah pihak, kemudian Ibu Iroh menerima sejumlah uang yang dipinjam dari murtahin yakni Ibu Nuryati. Begitu pula Ibu Nuryati menerima barang jaminannya yaitu lahan sawah. Penyerahan utang dan barang jaminan ini tentu saja melalui proses ijab qabul antara Ibu Iroh dan Ibu Nuryati. Ijab ini diucapkan oleh Ibu Iroh yang berbunyi: "Saya gadaikan lahan sawah ini dengan luas sawah seluas 200 bata dan saya terima pinjaman ini yang sejumlah Rp. 20.000.000", Lalu kemudian dijawab oleh Ibu Nuryati selaku murtahin, yang dalam hal ini disebut dengan qabul

\footnotetext{
${ }^{13}$ Obing dan Dedi Soibandi, Sekdes dan Kaur Desa, wawancara, Subang 27 Mei 2018

${ }^{14}$ Nuryanti, Ibu Rumah Tangga, wawancara, Subang, 22 Juni 2018
} 
Tinjauan Islam Terhadap Pemanfaatan Barang Gadai Sawah Di Desa Ciberes Kecamatan Patokbeusi Kabupaten Subang

yang berbunyi sebagai berikut, "Saya serahkan uang Rp. 20.000.000, dan saya terima lahan sawah tersebut." Setelah ijab qabul ini, menurut beliau maka secara otomatis hak kepemilikan dan hak penguasaan atas sawahnya yang dijadikan jaminan tersebut berpindah pada Ibu Nuryati, sehingga segala hak dan kewajiban yang melekat pada sawah tersebut berada ditangan Ibu Nuryati. ${ }^{1568}$

Sementara itu berkaitan dengan praktek gadai sawah ini, menurut pengamatan penulis, serta wawancara dengan beberapa tokoh masyarakat, dapat dijelaskan bahwa terdapat beberapa permasalahan atau kendala dalam pelaksanaan gadai tersebut, diantaranya sebagai yaitu:

1. Pembagian hasil dari pemanfaatan barang jaminan

Masalah ini muncul karena hasil dari pengelolaan sawah sebagai barang jaminan tidak dibagi rata. Bahkan si rahin terkadang tidak diberikan sedikitpun dari hasil keuntungan pengelolaan sawah oleh si murtahin. Hal ini tersebut muncul, karena menurut si murtahin bahwa si rahin tidak memiliki hak atas sawah yang dijadikan jaminan. Sehingga pemanfaatan sawah sepenuhnya hak si murtahin dan hasil dari pengelolaanpun sepenuhnya milik si murtahin.

2. Pembayaran marhun dengan di cicil

Di Desa Ciberes ada sebagian masyarakat yang melunasi pembayaran Marhun Bih (Utang) dengan cara dicicil, yaitu si rahin membayar utang tersebut dalam jangka waktu tempo 1 tahun (2 musim panen) kepada murtahin atas marhun. Biasanya si rahin dalam pembayarannya itu $2 x$ cicilan disertai tambahan bawaan berupa hasil panen (beras). Kebanyakan dalam pelaksanaan akad gadai timbul permasalah yang sama dikemudian hari. Hal ini salah satunya dilatarbelakangi oleh minimnya pengetahuan masyarakat pelaku gadai mengenai bagaimana pelaksanaan gadai itu benar.

Tinjauan Islam terhadap Pemanfaatan Barang Gadai Sawah di Desa Ciberes Kecamatan Patokbeusi Kabupaten Subang

1. Berdasarkan Rukun dan Syarat

Secara Terminologis dijelaskan bahwa rahn adalah menjadikan suatu barang sebagai jaminan atas utang, dengan ketentuan bahwa apabila terjadi kesulitan dalam pembayarannya maka utang tersebut dapat dibayar dari hasil penjualan barang yang dijadikan jaminan tersebut. ${ }^{16}$ Selanjutnya dijelaskan pula bahwa secara Prinsipil, rahn merupakan salah satu sarana tolong-menolong diantara

\footnotetext{
${ }^{15}$ Ibu Iroh, Orang Tua, wawancara, Subang, 25 Juni 2018.

${ }^{16}$ Ahmad Wardi Muslich, "Fiqh Muamalah", (Jakarta: Sinar Grafika Offset, 2010), hlm. 288
} 
Tinjauan Islam Terhadap Pemanfaatan Barang Gadai Sawah Di Desa Ciberes Kecamatan Patokbeusi Kabupaten Subang

sesama manusia dengan tanpa mengharapkan adanya imbalan jasa. ${ }^{170}$ Akad dalam hal ini dilaksanakan dengan akan pokok pinjam-meminjam dengan disertai barang jaminan yang berfungsi sebagai penjamin atas utang yang diambil, dan bukan untuk mengambil manfaat atau keuntungan dari barang jaminan tersebut.

Berdasarkan pada konsep tersebut, baik secara terminologis maupun prinsipil dapat penulis pahami bahwa dalam hal pelaksanaan gadai sawah di Desa Ciberes Kecamatan Patokbeusi Kabupaten Subang tersebut, telah terjadi kekeliruan penafsiran, yakni dalam hal pemanfaatan marhun yang dilaksanakan oleh murtahin (pemberi utang).

Berdasarkan data penulis peroleh bahwa pelaksanaan gadai sawah yang dilaksanakan di Desa Ciberes dari segi rukun gadai para pihak yang melaksanakan akad tersebut sudah memenuhi rukun gadai yang sesuai dengan hukum islam, karena dalam pernyataannya bahwa pemilik sawah atau rahin menyerahkan barang gadai (sawah) sebagai agunan atau jaminannya kepada murtahin, sedangkan rahin telah menerima utang atau uang dari murtahin. Kemudian terikat dengan orang yang berakad dalam pelaksanaan yaitu antara rahin dengan murtahin wajib melaksanakan akad yang telah disepakati bersama yaitu memberi barang gadai dari rahin dan menerima barang gadai dari rahin yaitu murtahin. Sehingga akad tersebut dapat berjalan dengan lancar dan tanpa ada kendala atau masalah yang diharapkan pihak yang berakad.

Sedangkan mengenai objek akadnya (mahallul 'aqd) dalam pelaksanaan akad gadai sawah yang dilaksanakan di Desa Ciberes yaitu berupa sawah yang dimiliki oleh rahin yang kemudian diserahkan kepada pihak murtahin, sedangkan rahin sendiri menerima utang dari murtahin yang berupa uang. Dalam pelaksanaan gadai sawah di Desa Ciberes masyarakat yang terlibat menyerahkan sepenuhnya barang gadai (sawah) dan utang (uang) kepada pihak yang melakukan akad gadai yang sesuai dengan rukun gadai dalam hukum islam.

Kemudian berkaitan dengan syarat gadai penulis mendapatkan data dari pelaksanaan gadai yang dilaksanakan di Desa Ciberes bahwa syarat bagi aqid dalam pelaksanaan akad gadai ialah aqid harus memiliki kecakapan (ahliyah), ${ }^{18^{71}}$ maksudnya ialah orang yang cakap untuk melakukan suatu perbuatan hukum sesuai dengan ketentuan syariat Islam, yaitu berakal dan baligh. Selain itu, aqid tidak berstatus dalam pengampuan (mahjur 'alaih). Bahkan dalam praktek gadai sawah tersebut dilaksanakan oleh rahin dan murtahin yang memiliki

\footnotetext{
${ }^{17}$ Nasrun Haroen, “Fiqih Muamalah", (Jakarta: Gaya Media Pratama, 2007), hlm. 251

${ }^{18}$ Ahmad Wardi Muslich, "Figh Muamalah", (Jakarta: Sinar Grafika Offset, 2010), hlm.290.
} 
Tinjauan Islam Terhadap Pemanfaatan Barang Gadai Sawah Di Desa Ciberes Kecamatan Patokbeusi Kabupaten Subang

kecakapan baik dari segi fisik maupun dari segi mental. Serta lahan sawah yang digunakan sebagai jaminan merupakan lahan milik rahin sendiri.

Berkaitan dengan barang yang akadkan bahwa dalam pelaksanaan gadai yang dilaksanakan di Desa Ciberes sendiri penulis mendapatkan bahwa pelaksanaan gadai harus ada jaminan yang berkriteria jelas dalam ijab qobul. Bahwa orang yang menggadaikan wajib menyerahkan barang jaminan kepada yang menerima gadai. Berkenaan dengan syarat yang melekat pada marhun atau rahn, para ulama menyepakati bahwasanya yang menjadi syarat yang harus melekat pada barang gadai merupakan syarat yang berlaku pada barang yang dapat dijualbelikan, dalam praktek gadai sawah tersebut marhun yang dimaksudkan ialah berupa sawah. Sementara itu yang berkaitan dengan marhun bihi ini harus merupakan barang yang dapat dimanfaatkan, apabila marhun bihi tidak dapat dimanfaatkan, maka tidak dianggap sah. Selain itu, marhun bihi haruslah merupakan barang yang dapat dihitung jumlahnya, dalam praktek gadai tersebut marhun bihi-nya berupa uang.

Berkenaan dengan ma'qud 'alaih tersebut, baik marhun (sawah) maupun marhun bihi langsung ada pada saat akad dilaksanakan. Yakni penyerahan uang dari murtahin secara langsung, dan penyerahan sawah secara lisan oleh rahin. Shigat yang dimaksud dalam pelaksanaan gadai sawah tersebut ialah berupa ucapan si penggadai yang berbunyi "saya gadaikan sawah di wilayah A dengan luas sekian", yang kemudian dijawab dengan ucapan dari si murtahin yang berbunyi: "saya terima gadai sawahnya". ${ }^{1972}$ Shigat ini yang dilaksanakan oleh rahin dan murtahin dalam pelaksanaan praktek gadai sawah di Desa Ciberes.

Akan tetapi, masalah justru timbul dalam kesepakatan yang terjadi diantara rahin dan murtahin, dimana ketika shigat (ijab qobul) keduanya menyepakati adanya ketentuan yang meyatakan bahwa selama rahin belum dapat mengembalikan pinjaman yang diambilnya, maka selama itu pula hak kepemilikan dan hak penguasaan atas lahan sawah yang dijaminkan berpindah ke tangan murtahin. Hal ini bertentangan dengan syarat shigat akad yang menyatakan bahwa shigat yang terdapat dalam akad gadai tidak boleh digantungkan (mu'allaq) dengan syarat tertentu yang bertentangan dengan substansi akad rahn. Smentara itu secara substansial dapat kita ketahui bahwa akad rahn ini merupakan suatu kegiatan menjadikan suatu barang sebagai jaminan atas utang, dengan ketentuan bahwa apabila terjadi kesulitan dalam pembayarannya maka utang tersebut dapat dibayar dari hasil penjualan barang

${ }^{19}$ Yahya, Kakek Penulis, wawancara, Subang, 6 Juni 2015. 
Tinjauan Islam Terhadap Pemanfaatan Barang Gadai Sawah Di Desa Ciberes Kecamatan Patokbeusi Kabupaten Subang

yang dijadikan jaminan tersebut. Sehingga jelas kemudian kita ketahui bahwa fungsi harta benda (sawah), hanyalah sebagai penjaminan saja, bukan objek yang dapat diambil pemanfaatan atasnya oleh murtahin, karena dalam hal ini hak murtahin hanya mempunyai hak untuk menahan marhun (lahan sawah), sementara hak kepemilikan atas marhun dan manfaatnya tetap berada ditangan rahin.

Selain itu, persyaratan lahan sawah yang dilakukan murtahin juga bertentangan dengan fungsi gadai yang merupakan sarana tolong- menolong antara sesama umat muslim (khususnya), umumnya bagi manusia, dengan tanpa adanya imbalan jasa. Berdasarkan penjelasan diatas dapat penulis amati bahwa praktek gadai sawah yang dilaksanakan di Desa Ciberes Kecamatan Patokbeusi Kabupaten Subang tersebut tidak sah karena ada salah satu bagian dari rukun gadai itu sendiri yang mengalami kerusakan, dalam hal ini yaitu shigat akad.

2. Berdasarkan Hak dan Kewajiban Rahin dan Murtahin

Menurut penulis terhadap permasalahan yang terjadi pada pelaksanaan gadai yang dilaksanakan di Desa Ciberes tersebut merupakan ketentuan khusus dalam praktek gadai yang termasuk dalam kaitannya dengan hak dan kewajiban para pihak yang melakukan akad gadai sawah, antara pihak yang menggadaikan (rahin) dan yang menerima barang gadai (murtahin), sehingga para fuqaha menyatakan dalam kaitannya antara rahin dan murtahin terhadap hak dan kewajibannya dengan barang gadai tersebut. Berdasarkan data yang penulis dapat dari lapangan berpendapat bahwa gadai itu berkaitan dengan keseluruhan hak pada barang yang digadaikan itu dan dengan sebagiannya. Yakni, jika seseorang menggadaikan sejumlah barang tertentu, kemudian ia melunasi sebagainya, maka keseluruhan barang gadai masih tetap berada di tangan penerima gadai hingga ia menerima hak keseluruhannya. ${ }^{20}$ Sebagai fuqaha berpendafat bahwa barang yang masih tetap berada di tangan penerima gadai hanya sebagiannya saja. Yakni sebesar hak yang belum dilunasi. Jumhur fuqaha beralasan bahwa barang tersebut tertahan sesuatu hak, karena itu setiap bagian dari hak tersebut harus tertahan juga. Ini serupa dengan tertahannya harta warisan (tirkah).

Sedangkan golongan kedua mengemukakan alasan bahwa keseluruhan barang itu tertahan oleh keseluruhan hak, karena itu sebagian barang tersebut

20 Ibnu Rusyd, "Analisa Fiqih Para Mujtahid", diterjemahkan oleh Imam Ghazali Said danAchmad Zaidun dari "Bidayatul Mujtahid Wanihatul Muqtashid", (Jakarta: Pustaka Amani, 2007), hlm. 200-201. 
Tinjauan Islam Terhadap Pemanfaatan Barang Gadai Sawah Di Desa Ciberes Kecamatan Patokbeusi Kabupaten Subang

tertahan oleh sebagai hak itu, dan ini serupa dengan tanggungan (kafalah). ${ }^{21}$ Menurut Hanafiyah, murtahin tidak boleh mengambil manfaat atas marhun dengan cara apa pun kecuali atas izin rahin. Hal tersebut dikarenakan murtahin hanya memiliki hak menahan marhun bukan memanfaatkannya. Apabila rahin memberi izin kepada murtahin untuk memanfaatkan marhun, maka menurut sebagian Hanafiyah, hal itu dibolehkan secara mutlak. Akan tetapi, sebagian dari mereka melarang secara mutlak, karena hal tersebut termasuk riba atau menyerupai riba. Menurut Malikiyah, apabila rahin mengizinkan kepada murtahin untuk memanfaatkan marhun atau murtahin mensyaratkan boleh mengambil manfaat maka hal itu dibolehkan, apabila utangnya karena jual beli atau semacamnya. Akan tetapi, apabila utangnya karena qardh (salaf) maka hal itu dibolehkan, karena hal tersebut termasuk utang yang menarik manfaat.

Syafiiyah secara global sama pendapatnya dengan Malikiyah yaitu bahwa murtahin tidak boleh mengambil manfaat atas barang yang digadaikan. Hal ini didasarkan kepada hadis Nabi SAW yang diriwayatkan oleh Abu Hurairah bahwa Rasulullah SAW bersabda: "Dari Abu Hurairah ra bahwa Rasulullah SAW bersabda: "Barang gadaian tidak menghalangi pemilik yang menggadaikannya (tidak boleh diakhiri kepemilikannya), Jadi keuntungan untuknya dan kerugiannya menjadi tanggungannya." (HR. Daruquthni dan Hakim dengan perawi-perawi yang dapat dipercaya. Namun yang terpelihara bagi Abu Dawud dan lainnya hadis itu mursal). Apabila murtahin mensyaratkan dalam akad utang piutang hal- hal yang merugikan kepada rahin, misalnya tambahan manfaat marhun untuk murtahin, maka menurut qaul yang azhar dikalangan Syafiiyah, syarat dan akad gadai menjadi batal. ${ }^{22}$

"Dari Jabir, ia berkata: Rasulullah melaknat pemakan riba, pemberi makan riba, penulisnya, dan dua orang saksinya. Rasulullah berkata: "Mereka itu sama semuanya". (HR. Muslim) ${ }^{23}$

Dan apabila murtahin mensyaratkan dalam akad utang piutang hal-hal yang merugikan kepada rahin, misalnya tambahan atau manfaat barang gadai untuk murtahin, maka menurut penulis bersumber dari pendapat qaul yang azhar di kalangan Syafiiyah, syarat dan akad gadai menjadi batal. Hal ini didasarkan kepada hadis yang berbunyi yang artinya sebagai berikut: "Berkata

21 Ibnu Hajar Al-Asqalani, "Bulugul Maram", Penerjemah Harun dan Zenal Mutaqin, (Bandung: Penerbit Jamal, 2014), Cet. 6, hlm. 214.

${ }^{22}$ Ahmad Wardi Muslich, "Fiqh Muamalah", (Jakarta: Sinar Grafika Offset, 2010), hlm. 309.

23 Ibnu Hajar Al-Asqalani, "Bulugul Maram", Penerjemah Harun dan Zenal Mutaqin, (Bandung: Penerbit Jamal, 2014), Cet. 6, hlm. 206. 
Tinjauan Islam Terhadap Pemanfaatan Barang Gadai Sawah Di Desa Ciberes Kecamatan Patokbeusi Kabupaten Subang

Ibnu Umar atau Umar: Setiap syarat yang bertentangan dengan kitab Allah maka hukumnya batal, walaupun menetapkan seratus syarat." (HR. Al-Bukhari).

Hanabilah berpendapat, untuk barang gadai selain binatang, yang tidak memerlukan biaya (makan), seperti rumah, barang-barang dan lain-lain, murtahin tidak boleh mengambil manfaat kecuali dengan persetujuan rahin. Hal itu dikarenakan barang gadai, manfaat, dan pertambahannya merupakan milik rahin, sehingga orang lain tidak boleh mengambil tanpa persetujuannya. Apabila rahin mengizinkan murtahin untuk mengambil manfaat tanpa imbalan ('iwadh), dan utangnya disebabkan qard maka murtahin tidak dibolehkan mengambil manfaatnya, karena hal tersebut berarti utang yang menarik manfaat, dan itu hukumnya haram. Untuk barang gadai yang berupa binatang, murtahin boleh mengambil manfaatnya, apabila binatang tersebut termasuk jenis binatang yang dikendarai atau diperah. Hal itu sebagai pengganti biaya yang dikeluarkan untuk binatang tersebut, walaupun rahin tidak mengizinkannya.

3. Pembayaran Marhun Bih atas Marhun dengan cara Dicicil

Pembayaran marhun bih (utang) atas marhun (barang jaminan gadai) dengan cara di cicil itu diperbolehkan oleh Islam. yang tidak dibolehkan secara Islam yaitu adanya tambahan tertentu yaitu hasil panen yaitu beras atau yang lainnya, itu dapat dikategorikan dalam akad qard yang mensyaratkan tambahan tertentu, dan akad qard tersebut dapat dikategorikan semacam riba. Allah SWT berfirman dalam Surat Al-Baqarah ayat 275:

"orang-orang yang makan (mengambil) riba tidak dapat berdiri melainkan seperti berdirinya orang yang kemasukan syaitan lantaran (tekanan) penyakit gila. Keadaan mereka yang demikian itu, disebabkan mereka berkata (berpendapat), sesungguhnya jual beli itu sama dengan riba, padahal Allah telah menghalalkan jual beli dan mengharamkan riba. Orang-orang yang telah sampai keadaannya larangan dari Tuhannya, lalu terus berhenti (dari pengambil riba), maka baginya apa yang telah diambilnya dahulu (sebelum datang larangan); dan urusannya (terserah) kepada Allah. Orang yang kembali (mengambil riba), maka orang itu adalah penghuni-penghuni neraka; mereka kekal di dalamnya". (QS. Al-Baqarah: 275).

Berkenaan dengan pendapat ulama diatas, Penulis menyimpulkan bahwa pelaksanaan gadai sawah yang dilaksanakan di Desa Ciberes tidak sesuai dengan hukum islam yang disepakati oleh ulama fiqh atau jumhur fuqaha. Karena akad dan syarat yang ditempuh oleh rahin dan murtahin tidak lengkap dengan rukun dan syarat gadai, sedangkan hak dan kewajiban antara rahin dan murtahin yang disini khusus bagi si murtahin, bahwa si murtahin tidak boleh menggunakan 
Tinjauan Islam Terhadap Pemanfaatan Barang Gadai Sawah Di Desa Ciberes Kecamatan Patokbeusi Kabupaten Subang

atau memanfaatkan barang gadai (sawah) yang dilakukan oleh rahin dan murtahin di Desa Ciberes. Karena dalam akad gadai tersebut tidak diucapkan oleh pemberi gadai (rahin) sehingga apabila si murtahin memanfaatkan barang gadai tersebut si rahin harus mengambil kembali barang gadai itu, karena murtahin haknya hanya menahan barang gadai itu, bukan memanfaatkan barang gadai tersebut. Di tambah adanya tambahan bayaran marhun yang di cicil berupa hasil panen yaitu berupa beras dan yang lainnya.

\section{SIMPULAN}

Pemanfaatan Barang Gadai di Desa Ciberes Kecamatan Patokbeusi Kabupaten Subang terjadi sebagai berikut: Pertama, si rahin tersebut mengalami ekonomi yang mendesak terlebih dahulu memberi tahu besarnya uang yang akan dipinjam dan menawarkan barang yang akan dijadikan barang jaminan yaitu berupa sawah kepada murtahin. Kedua, proses ijab qobul dilaksanakan dan dari keduanya ada saksinya, tapi biasanya pihak desa tidak dilibatkan. Ketiga, setelah proses ijab qabul itu selesai biasanya murtahin memanfaatkan marhun tersebut berupa sawah, yang biasanya oleh si murtahin di garap sawah tersebut. Keempat, rahin mencicil utang gadaiannya tersebut selama 2 kali panen ( 1 tahun) dan memberikan sebagian hasil panen berupa beras kepada murtahin. Tinjauan Islam terhadap Pemanfaatan Barang Gadai Sawah di Desa Ciberes Kecamatan Patokbeusi Kabupaten Subang diduga kuat bertentangan dengan hukum Islam, dengan argumentasi sebagai berikut: Pertama, bahwa pemanfaatan barang jaminan (sawah) tersebut dapat dikategorikan dalam akad qard yang mensyaratkan tambahan tertentu, dan ini tidak dibolehkan oleh agama dan dapat dikategorikan ke dalam macam riba. Kedua, pemanfaatan barang jaminan oleh murtahin ini keluar dari ketentuan bahwa yang berhak memanfaatkan suatu barang ialah pemiliknya, sementara murtahin bukan pemiliknya sehingga yang berhak mengambil manfaat atas barang jaminan gadai ialah pemberi gadai, hal ini tetap berlaku meskipun barang tersebut pada dasarnya berada di bawah kekuasaan penerima gadai. Ketiga, ketentuan kedudukan barang tersebut sebagai jaminan atau kepercayaan atas murtahin, namun kepemilikan atasnya tetap melekat pada pemiliknya yakni pemberi gadai. Keempat, adanya pemanfaatan jaminan oleh penerima gadai menyebabkan turunnya kualitas jaminan, dan hal ini tidak dibenarkan adanya izin dari pemberi gadai.

\section{DAFTAR PUSTAKA}

"Kitab Undang-Undang Hukum Perdata", Tangerang Selatan: SL Media, 2010 2010. 
Tinjauan Islam Terhadap Pemanfaatan Barang Gadai Sawah Di Desa Ciberes Kecamatan Patokbeusi Kabupaten Subang

Adi Riyanto, "Metodologi Penelitian Sosial dan Hukum", Jakarta: Granit, 2004. Aji Damanuri, Metodologi Penelitian Muamalah, Yogyakarta: Stain Po Press, Adrian Sutedi, "Hukum Gadai Syariah", Bandung: Alfabeta, 2011.

Ahmad Wardi Muslich, "Fiqh Muamalah", Jakarta: Sinar Grafika Offset, 2010. Nasrun Haroen, "Fiqih Muamalah", Jakarta: Gaya Media Pratama, Cet. 2, 2007.

Chairuman Pasaribu, Suhrawardi K. Lubis, "Hukum Perjanjian Dalam Islam", Jakarta: Sinar Grafika, 1996.

DSN-MUI, "Himpunan Fatwa Dewan Syariah Nasional", Jakarta: CV. Gaung http://blog-mheighap.blogspot.com/2013/06/pengertian-penggadaian-secarahttp://hadisbukhari.blogspot.com/2012/04/bab-31-gadai.html. http://hepeng50.blogspot.com/2011/03/hak-dan-kewajiban-penerima-gadai.html http://statushukum.com//tujuan-hukum-islam.html http://www.ipapedia.web.id/2015/01/pengertian-dan-tujuan-tinjauanhttp://www.quran30.net. Ibnu Rusyd, "Analisa Fiqih Para Mujtahid", diterjemahkan oleh Imam Ghazali Said dan Achmad Zaidun dari "Bidayatul Mujtahid Wanihatul Muqtashid", Jakarta: Pustaka Amani, Cet. II, 2007.

Ismail Nawawi, "Fikih Muamalah Klasik dan Kontemporer", Bogor: Ghalia Konstruksi Pegadaian Nasional Edisi ke-1", Jakarta: Salemba Diniyah, 2003.

Data Potensi Desa Ciberes up date Tahun 2015.

Lexy J. Monoeng, "Metode Penelitian Kualitatif", Bandung, PT. Remaja Muh. Syafi'i Antonio, "Bank Syariah Suatu Pengenalan Umum", Jakarta: Tazkia Muhammad dan Sholikhul Hadi, "Pegadaian Syariah: Suatu Alternatif Muhammad Syafi'i Antonio, "Bank Syariah: Wacana Ulama dan Cendekiawan", Jakarta: Bank Indonesia dan Tazkia Institute, 2001.

Wahbah Az-Zuhaili, "Fiqih Islam Wa Adillatuhu Jilid 6", Jakarta: Gema Insani, Zainuddin Ali, "Hukum Gadai Syariah", Jakarta: Sinar Grafika, 2008. 